\title{
Therapeutic effect of Aloe vera and silver nanoparticles on acid-induced oral ulcer in gamma-irradiated mice
}

\begin{abstract}
Ahmed Ibrahim EL-BATAL (a) Salwa Farid AHMED(b)
\end{abstract}

(a) National Centre for Radiation Research and Technology - NCRRT, Atomic Energy Authority, Drug Radiation Research Department, Nasr City, Cairo, Egypt.

(b) National Centre for Radiation Research and Technology - NCRRT, Atomic Energy Authority, Health Radiation Research Department, Nasr City, Cairo, Egypt.

Declaration of Interests: The authors certify that they have no commercial or associative interest that represents a conflict of interest in connection with the manuscript.

Corresponding Author:

Salwa Farid Ahmed

E-mail: salwaafared@yahoo.com

Submitted: May 30, 2017

Accepted for publication: Nov 27, 2017

Last revision: Dec 12, 2017
Abstract: Radiation combined injury, a life-threatening condition, has higher mortality than simple radiation injury. The aim of the present study was to analyze the efficiency of Aloe vera and silver nanoparticles in improving the healing of ulcerated oral mucosa after irradiation. Thirty male Albino mice were divided into five groups: control, radiation, Aloe vera $(\mathrm{AV})$, silver nanoparticles (NS), and $\mathrm{AV}+\mathrm{NS}$. The mice were exposed to whole body 6Gy gamma-radiation. After one hour, $20 \%$ acetic acid was injected into the submucosal layer of the lower lip for ulcer induction. The animals received topical treatment with the assigned substances for 5 days. Lip specimens were subjected to hematoxylin and eosin and anti alpha-smooth muscle actin immunohistochemical staining. Results demonstrated occurance of ulcer three days post irradiation in all groups except in the AV+NS group where only epithelial detachment was developed. After seven days, data revealed persistent ulcer in radiation group, and almost normal epithelium in the AV+NS group. A significant reduction of epithelial thickness was detected in all groups at the third day as compared to control. At the seventh day, only the AV+NS group restored the epithelial thickness. Area percent of alpha-smooth muscle actin expression was significantly decreased in radiation group at the third day followed by significant increase at the seventh day. However, all treatment groups showed significant increase in alpha-smooth muscle actin at the third day, which decreased to normal level at the seventh day. Our study demonstrated the efficiency of Aloe vera and silver nanoparticles in enhancing ulcer healing after irradiation.

Keywords: Aloe; Nanoparticles; Ulcer; Radiation Injuries; Wounds and Injuries.

\section{Introduction}

Sufferers of nuclear and radiological accidents usually present radiation injury (RI) alone or combined with other types of injury such as physical, chemical and thermal trauma (radiation combined injury, $\mathrm{RCI}){ }^{1} \mathrm{RCI}$ is considered a life-threatening condition that increases mortality compared to RI, despite each injury alone might not be fatal. ${ }^{2}$

Several studies on different animal models have demonstrated that non-lethal injuries (wound, burn or bacterial infection) induced after 
radiation exposure increase cell death, tissue damage, organ dysfunction, mortality, DNA damages, and severe and rapid loss of hematological components compared to radiation exposure alone. ${ }^{3}$

The loss of oral mucosa cells is continuously compensated by proliferation of epithelial cells of the basal layer. ${ }^{4}$ Irradiation significantly diminishes the barrier function of the epithelium against different insults (mechanical, chemical and microbial), impairing the balance between cell proliferation and death. These effects can be further aggravated by additional trauma with subsequent ulcer formation and complete cellular depletion.., 6

Recently, great attention has been directed toward therapeutic natural products as they results in less side effects. ${ }^{7}$ Aloe vera (AV), a tropical plant, has been used for centuries for therapeutic purposes. ${ }^{8}$ The gel extracted from the leaf parenchyma contains a wide range of natural components that possess significant anti-inflammatory, antioxidant, antifungal and angiogenic activities and has shown ability to improve the healing of gastric ulcers, ${ }^{9}$ infected leg ulcers ${ }^{10}$ and recurrent aphthous ulcers. ${ }^{11}$

Nowadays, the use of new medicinal preparations at nanoscale levels is widespread. Silver nanoparticles (AgNPs) of $100 \mathrm{~nm}$ dimension or less have unique physical, chemical and biological properties. ${ }^{12}$ AgNPs are considered one of the most promising nanomaterials, with an efficient antimicrobial effect of a broad spectrum of bacteria, in addition to anti-inflammatory, ${ }^{13}$ antifungal, ${ }^{14}$ and antiviral effects. ${ }^{15}$ Many researchers demonstrated effective use of AgNPs as treatment for burns, chronic ulcers, toxic epidermal necrolysis, and pemphigus. ${ }^{16}$

Although AV gel and AgNPs are effective in the treatment of various types of ulcers, their efficiency in radiation combined oral ulceration has not yet been reported. Therefore, the aim of the current study was to evaluate the effects of topical application of these agents on oral ulcer healing in irradiated mice.

\section{Methodology}

\section{Animals}

Thirty male Albino mice weighing 50-70 g were used for this study. Animals were housed in specially designed cages (6 mice per cage), in a room with controlled temperature $\left(25 \pm 3^{\circ} \mathrm{C}\right)$, humidity, and 12-h light/dark cycle. All animals were fed with semi-purified diet and water ad libitum for ten days before inception of the experiment. The experimental protocol was accepted by the Department of Animal care, Cairo University, that follows the European Communities Council guiding principles for the care and use of laboratory animals.

\section{Experimental groups}

The mice were randomly classified into five groups ( $n=6$ in each group). One group received no treatment and was used as the control group (C). Another group $(\mathrm{R})$ was submitted to radiation and oral ulcer induction and received no treatment. Groups $\mathrm{AV}, \mathrm{NS}$ and $\mathrm{AV}+\mathrm{NS}$ were submitted to radiation and oral ulcer induction and were treated topically with AV gel $(0.25 \mathrm{ml} / \mathrm{kg})$, aqueous solution of AgNPs $(2 \mathrm{mg} / \mathrm{kg})^{17}$ and the combination of both treatments for five days, respectively.

\section{Irradiation}

Whole body irradiation of animals was performed at The National Center for Radiation Research and Technology (NCRRT), Cairo, Egypt, using Gamma cell 40 (Cs 137). Mice were exposed to a single dose of $6 \mathrm{~Gy}$ (dose rate of $0.43 \mathrm{~Gy} / \mathrm{min}$ ).

\section{Ulcer induction}

The animals were fasted with access to water $12 \mathrm{~h}$ before the experiment. One hour after irradiation, the animals were anesthetized, then $20 \%$ acetic acid $(0.01 \mathrm{~mL})$ was injected into the submucosal layer of the lower lip.

\section{Aloe vera preparation}

$\mathrm{AV}$ gel was prepared according to Banu et al..$^{10}$ The outer layer of spotted Aloe barbadensis was peeled, the inner gel was obtained using a sterile spatula and then the gel was filtered and sterilized. The gel was stored in a sterile container at room temperature for immediate use.

\section{Silver nanoparticles synthesis and characterization}

$\mathrm{AgNO}_{3}$ and polyvinylpyrrolidone (PVP) solutions were used for the synthesis of AgNPs. The modified 
method was applied as follows: $10 \mathrm{~mL}$ of $0.3 \%$ PVP solution was mixed with $90 \mathrm{~mL}$ of $2.0 \mathrm{mM} \mathrm{AgNO}_{3}$ solution and $0.2 \%$ isopropanol as the free radical scavenger. The mixtures were exposed to gamma radiation at $25 \mathrm{kGy}$ doses at room temperature at the NCRRT. The facility used the 60Co-Gamma chamber 4000-A-India. Irradiation was administered at a $2.9 \mathrm{kGy} / \mathrm{hr}$ dose rate at the time of the experiment. ${ }^{18}$

Characterization of AgNPs was performed through transmission electron microscopy (TEM model JEOL electron microscopy JEM-100 CX). In the TEM micrographs of PVP-AgNPs, the particles appeared spherical and remained fairly dispersed ranging from $10.4 \mathrm{~nm}$ to $17.6 \mathrm{~nm}$ with mean diameter of $14.91 \mathrm{~nm}$ as presented in Figure 1.

\section{Histological and immunohistochemical analysis}

Three mice from each group were sacrificed by cervical dislocation three and seven days after irradiation. The lower lip was dissected, fixed in $10 \%$ formalin and embedded in paraffin. Sections were cut at a thickness of $5 \mu \mathrm{m}$ and stained with hematoxylin and eosin (H\&E) for histopathological evaluation under the light microscope with $\times 400$ magnification by pathologists. Other sections of $5 \mu \mathrm{m}$ were placed on poly-L-Lysine coated slides and stained using mouse monoclonal antibodies to evaluate alpha-smooth muscle actin (a-SMA) expression (Santa Cruz Biotechnology, USA). Both

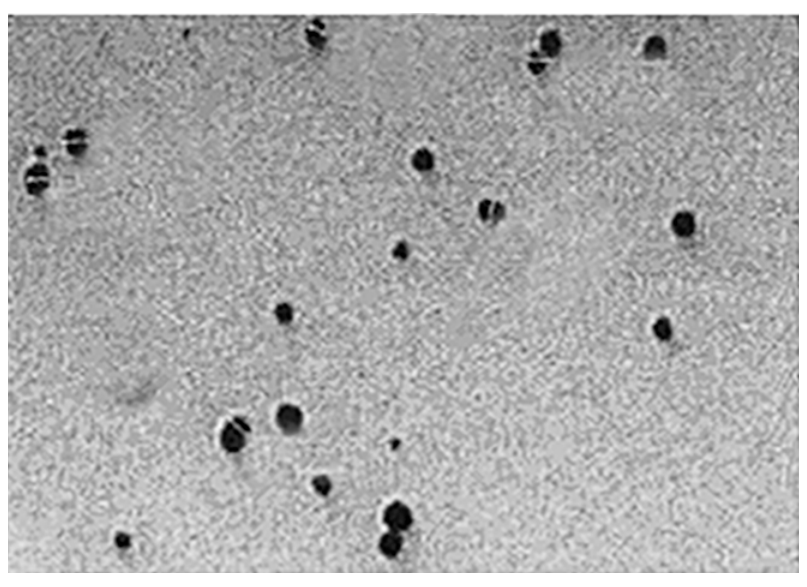

Figure 1. Transmission electron microscopy image of polyvinylpyrrolidone (PVP) silver nanoparticles (AgNPs). epithelial thickness $(\mu \mathrm{m})$ and area percent of cells expressing a-SMA were measured in 5 histological fields $(\times 400)$ randomly captured in each slide with a digitized image analysis system using the software Leica Qwin 500.

\section{Statistical analysis}

Data are reported as mean \pm standard deviation (SD). One-way analysis of variance was performed to compare group differences. Multiple range test was used when differences among groups were significant. Statistical analysis was done by using Statgraphics Centurion XVI software, Statpoint Technologies, Inc., 560 Broadview Ave. Warrenton, Virginia 20182. $\mathrm{P}<0.01$ was considered highly significant.

\section{Results}

\section{H\&E staining}

\section{Three days post-ulceration:}

The normal (group C) lower lip consisted of thin stratified squamous epithelium with a thin keratin layer. The underlying connective tissue contained normal blood vessels and muscles (Figure 2A). The lower lip of group $\mathrm{R}$ revealed extensive loss of surface epithelium continuity (ulcerated), homogeneous connective tissue with massive inflammatory infiltrate

Table. Thickness of lower lip epithelium ( $\mu \mathrm{m}$, mean \pm SD) after oral ulcer induction throughout the experimental period and in the different groups: C, control; R, irradiated; $A V$, Aloe vera; NS, silver nanoparticles.

\begin{tabular}{|c|c|c|}
\hline \multirow{2}{*}{ Group } & \multicolumn{2}{|c|}{ Days } \\
\hline & $3^{\text {rd }}$ & $7^{\text {th }}$ \\
\hline C & $39.19 \pm 3.54$ & $40.86 \pm 3.11$ \\
\hline$R$ & $0.96 \pm 0.32 \mathrm{ac}$ & $1.32 \pm 0.32 \mathrm{ac}$ \\
\hline AV & $1.93 \pm 0.53 \mathrm{ac}$ & $51.21 \pm 3.31 \mathrm{ac}, \mathrm{ar}, \mathrm{ad}$ \\
\hline NS & $2.73 \pm 0.77 \mathrm{ac}$ & $69.05 \pm 6.23 \mathrm{ac}, \mathrm{ar}, \mathrm{ad}$ \\
\hline $\mathrm{AV}+\mathrm{NS}$ & $10.01 \pm 1.27 \mathrm{ac}, \mathrm{ar}$ & $43.09 \pm 2.80 \mathrm{ar}, \mathrm{ad}$ \\
\hline $\mathrm{p}(\mathrm{I})$ value & $<0.0001$ & $<0.0001 w$ \\
\hline
\end{tabular}

Significant difference between groups: (ac) versus control group, (ar) versus irradiated group. Significant difference between same group: (ad) at 3rd day. $P(I)$ : significant difference between different experimental groups within the same interval. $P$ value $<0.01$ was considered highly significant. 
and areas of hemorrhage (Figure 2B). Specimens from group $\mathrm{AV}$ revealed similar changes to the $\mathrm{R}$ group but with less inflammatory reaction (Figure 2C). The epithelium of NS group was detached from the underlying connective tissue that contained few inflammatory cells and dilated blood vessels. On the periphery of the ulcer, the basal layer of the epithelium was still attached to the connective tissue (Figure 2D). In $\mathrm{AV}+\mathrm{NS}$ group, almost intact mucosa with a thin keratin layer was detected, and only a few areas of separation within the epithelium. Vacuolization of different epithelial cells were found (Figure 2E). Histomorphometric analysis showed that 3 days post-ulceration the epithelial thickness (ET) of all groups significantly decreased compared to control group ( $p>0.05)$, however, the smallest thickness was detected in group $\mathrm{R}$ while the highest thickness was found in group $\mathrm{AV}+\mathrm{NS}$ (Table).

\section{Seven days post-ulceration:}

At the 7th day post-ulceration, the changes in the lower lip of group R were still microscopically visible (Figure 3A). Group AV exhibited hyperplastic epithelium with cellular vacuolization and restoration of the keratin layer. Proliferating fibroblasts and some degenerated muscle were detected (Figure 3B). The epithelium of group NS was hyperplastic with excessive keratinization. A high number of proliferating fibroblasts were observed (Figure 3C). The group AV+NS showed normal epithelium with a thin keratin layer. The connective tissue was nearly normal and contained normal blood vessels (Figure 3D).

The ET varied between groups. In group R, the ET was slightly increased but still significantly reduced compared to the control group. The epithelium of groups AV and NS showed significant increase in thickness compared to control group or the 3rd day value. The ET of group $\mathrm{AV}+\mathrm{NS}$ significantly increased compared to the 3 rd day being somewhat similar to the control group (Table).

\section{Alpha-smooth muscle actin immunostaining}

Area percent of cells expressing a-SMA, a marker of activated fibroblasts and endothelial cells, was calculated at 3 and 7 days post-ulceration.
Compared to the control, there was significant reduction of the area occupied by activated fibroblasts and mature vascular endothelial cells in the ulcer area of group $\mathrm{R}$ at the 3rd day postulceration. Groups AV, NS and AV+NS showed significantly higher area percent of activated fibroblasts and mature vascular endothelial cells in the ulcer area (Figure 4A).

At the 7th day post-ulceration, group $\mathrm{R}$ had significantly higher area percent of activated fibroblasts and mature vascular endothelial cells in the ulcer area. On the other hand, the other groups showed decreased area percent of a-SMA positive cells with no significant difference compared to the control (Figure 4B).

\section{Discussion}

Most international guidelines are directed toward early management of exposure to whole-body irradiation alone, however, victims of radiation accidents often suffer from other insults. Because of the insufficiency of human data or clinical cases of RCI, animal models are perfect to evaluate the efficiency of possible countermeasures. ${ }^{19}$. Mice are the 1st choice when oral mucosa is under investigation because of the structural similarity between the oral mucosa of mice and humans. Moreover, mice are inexpensive, and easily manipulated and maintained under controlled condition. ${ }^{20}$

Wound healing is a highly ordered multicellular process. Optimum healing depends mainly on organized cellular interactions that control different overlapping healing phases. ${ }^{21}$ Wound contraction is mainly regulated by modulated fibroblasts known as myofibroblasts, ${ }^{22}$ which express many contractile proteins, among them a-SMA. ${ }^{23}$ It is well known that fibroblasts expressing elevated a-SMA show more contractile activity compared to those expressing low a-SMA. The contactile activity of fibroblasts expressing low a-SMA can be enhanced by treatment with many substances that increase a-SMA level. ${ }^{23}$

Radiation affects the process of wound closure by decreasing the regenerative competence of oral epithelium, ${ }^{24}$ and subsequent injury to an irradiated 

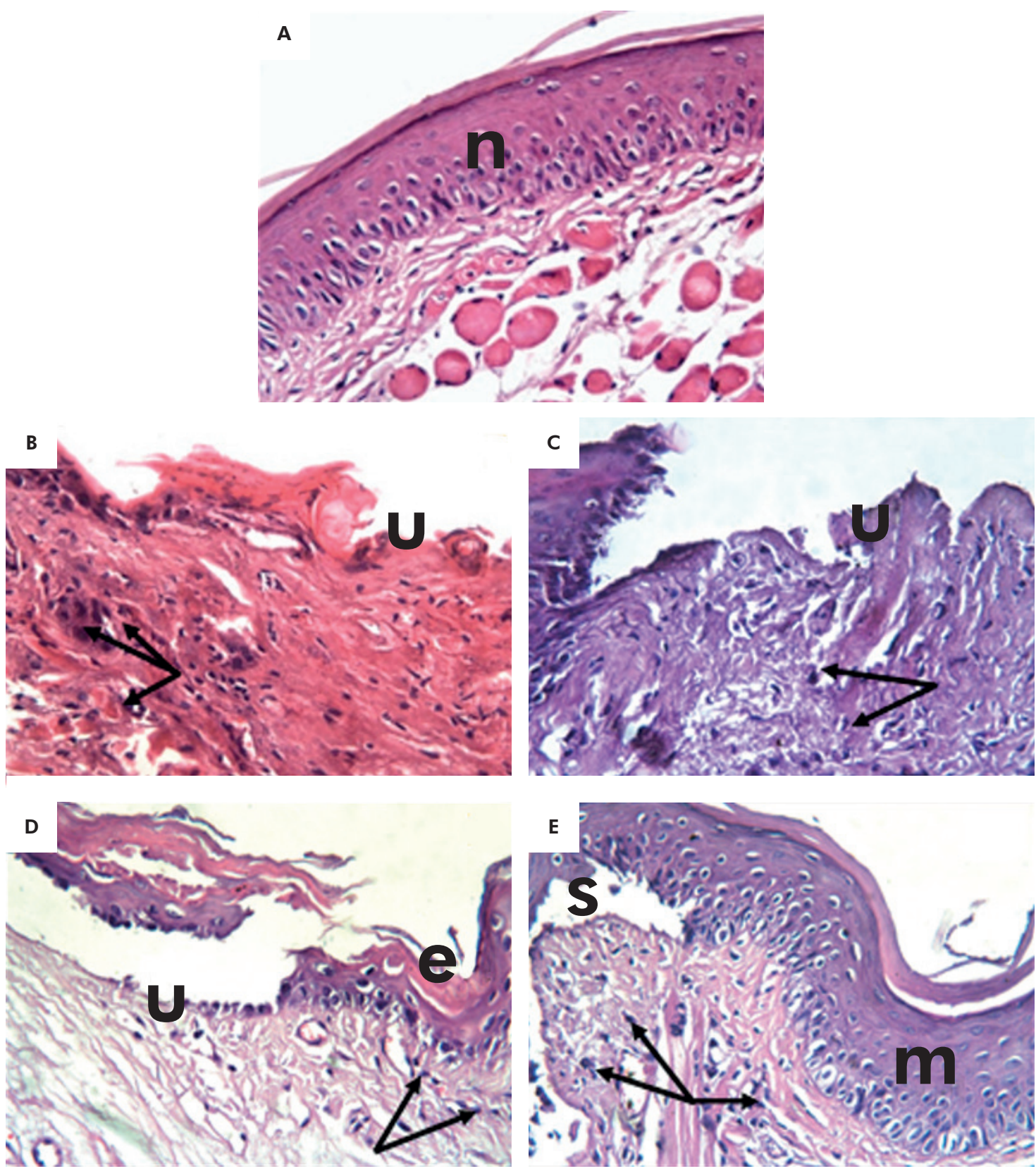

Figure 2. Photomicrograph of the lower lip at the 3rd day post-ulceration of (A) group $C$, (B) group $R,(C)$ group $A V$, (D) group NS, and $(E)$ group $A V+N S$, showing normal epithelium with thin keratin layer (n), ulcerated oral epithelium (u), chronic inflammatory cells (black arrow), retained epithelium (e), almost intact epithelium with cellular vacuolization (m) and area of epithelial separation (s). H\&E $\times 400$.

site can trigger a sever uncontrolled reaction. ${ }^{6}$ In this study, oral ulcer was induced in gamma-irradiated mice as a model of RCI. The demonstrated inflammatory changes, homogeneous connective tissue and reduced ET of the ulcer area in the irradiated group were in accordance with findings obtained by Li et al..$^{25}$ Radiation can directly damage DNA of cells with subsequent cell apoptosis or necrosis. This can explain the reduced renewal capacity of the epithelium and persistence of the ulcer. ${ }^{26}$

Our study found that AV or AgNPs alone did not affect actual ulcer formation but improved ulcer healing with restoration of epithelium integrity, areas of hyperplasia, and almost normal underlying 

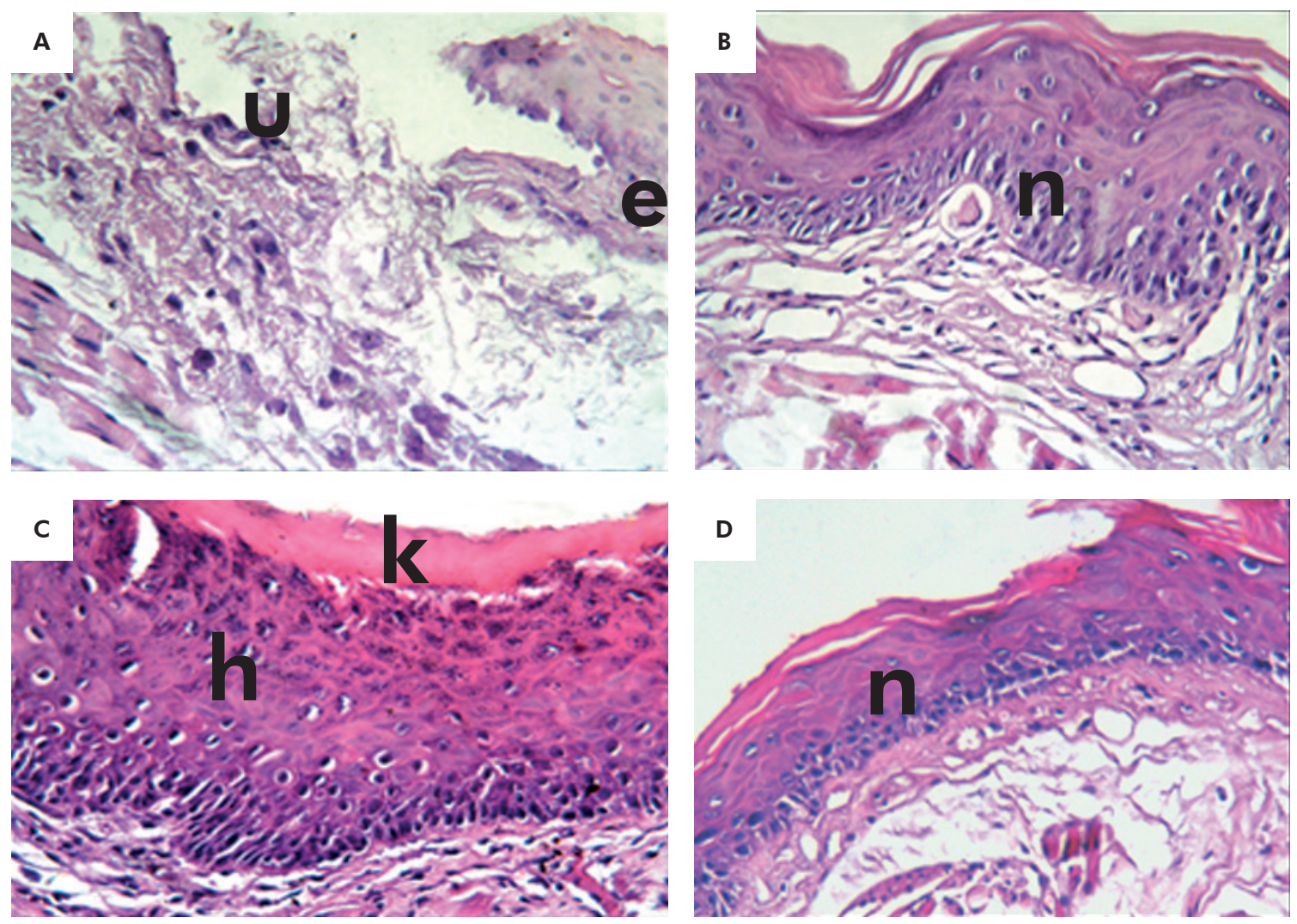

Figure 3. photomicrograph of the lower lip at the 7th day post-ulceration of (A) group $R$, (B) group $A V$, (C) group NS, and (D) group $\mathrm{AV}+\mathrm{NS}$ showing ulcerated epithelium (u), retained epithelium (e), normal epithelium with thin keratin layer (n), hyperplastic epithelium (h), and hyperkeratosis (k). H\&E $\times 400$.
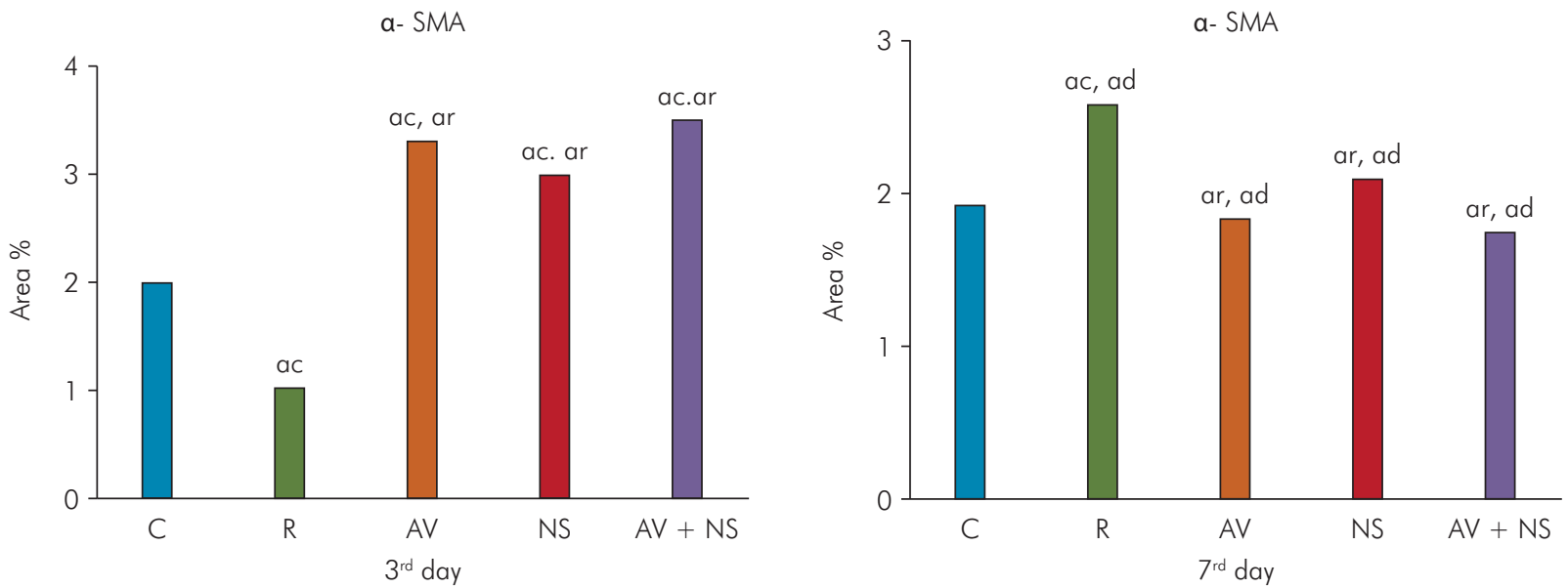

*Significant difference between groups: (ac) versus control group, (ar) versus irradiated group. Significant difference between same group (ad) at $3^{\text {rd }}$ day.

Figure 4. Area percent of activated fibroblasts and mature vascular endothelial cells expressing $\alpha$-SMA in ulcer area is shown at (A) $3^{\text {rd }}$ day and (B) $7^{\text {th }}$ day post-ulceration. 
connective tissue free from inflammatory infiltrate. Their combined use prevented ulcer formation, presenting only epithelial detachment from underlying connective tissue and after 7 days was similar to intact tissue with normal thickness.

Many researchers reported the effectiveness of $\mathrm{AV}$ as a promoter of burn wound healing ${ }^{27}$ and gastric ulcer healing ${ }^{9}$ in addition to its ability to reduce tissue loss and improve healing in frost bite injury. ${ }^{28}$ Others found that AgNPs significantly promoted wound healing of infected wounds, ${ }^{29}$ and deep partial-thickness wounds. ${ }^{30}$

Significant epithelial loss was detected in all groups at day 3. The loss was of $98 \%$ in group R, $95 \%$ and $93 \%$ in $\mathrm{AV}$ and NS groups and $74 \%$ in $\mathrm{AV}+\mathrm{NS}$ group. At the 7th day, group $\mathrm{R}$ revealed significant epithelial loss (97\%), while group AV and NS showed significant hyperplasia at 25 and $70 \%$ ratio, respectively. On other hand, group $\mathrm{AV}+\mathrm{NS}$ revealed normal epithelial thickness.

The decreased epithelial loss and improved ulcer healing can be attributed to the anti-inflammatory effect of AV through the elevation of IL-10 level, which inhibits cytokine synthesis by macrophages and suppresses TNF- $\alpha$ production. ${ }^{8,9}$ In addition, AV stimulates PGE2, TGF- $\beta-1$ and bFGF production and induces angiogenesis, which play important roles in the maintenance of mucosal integrity and wound healing. ${ }^{31}$ Moreover, AV enhances production of KGF-1 and VEGF by gingival fibroblast $\mathrm{s}^{32}$ and maintaines the wound moisturized, promotes epithelial cell migration, and enhances collagen maturation. ${ }^{33}$

AgNPs exerts its healing effect by decreasing bacterial and fungal count at wound site. The mechanisms are through disruption of the cell membrane causing cell death and the ability to block respiratory enzyme pathways, alter microbial DNA and inhibit the normal fungal budding process. ${ }^{14,34}$ (Melayie, 2005 \#32;Nasrollahi, 2011 \#14). Moreover, AgNPs enhances the process of reepithelialization ${ }^{31}$, which can be attributed to the ability of down-regulating inflammatory response, decreasing cytokine and matrix metalloproteinases level and inducing apoptosis of inflammatory cells, leading to earlier wound healing. ${ }^{35}$

The reduced number of activated fibroblasts and mature vascular endothelial cells at the 3rd day, which increased by the 7th day, was also detected in irradiated salivary glands and attributed to cell cycle arrest due to delay of the $S$ phase. ${ }^{5} \mathrm{AV}$ and AgNPs alone or in combination increased the number of activated fibroblasts and mature vascular endothelial cells at the 3 rd day. This result is in agreement with Liu et al., ${ }^{36}$ who reported that AgNPs enhanced fibroblast transformation into myofibroblast. Similarly, Liu et al., ${ }^{37}$ found that AV increased fibroblast proliferation and collagen synthesis, and elevated hyaluronic acid and hydroxyproline level, which suggest a possible role in the extracellular matrix remodeling during wound healing. Another study attributed the effect of AV to the binding of mannose-6-phosphate, an essential component of $\mathrm{AV}$, to fibroblast receptors, activating their proliferation, ${ }^{38}$ thus stimulating collagen synthesis and increasing the healing area. ${ }^{39}$ The decrease in the number of activated fibroblasts and mature vascular endothelial cells at the 7 th day might be related to the almost complete healing process.

The limitation faced in this study was the inability to measure ulcer length, width or size due to lack of measurement devices. We suggest further studies to evaluate the clinical outcome of ulcer healing by AV and AgNPs.

\section{Conclusion}

In conclusion, $\mathrm{AV}$ and $\mathrm{AgNPs}$ could be effective treatments to promote ulcer healing of radiation combined injury through their anti-inflammatory, enhanced re-epithelialization and fibroblast activation effects. 
Therapeutic effect of Aloe vera and silver nanoparticles on acid-induced oral ulcer in gamma-irradiated mice

\section{References}

1. Ledney GD, Elliott TB. Combined injury:

factors with potential to impact radiation dose

assessments. Health Phys. 2010 Feb;98(2):145-52.

https://doi.org/10.1097/01.HP.0000348466.09978.77

2. DiCarlo AL, Maher C, Hick JL, Hanfling D, Dainiak N,

Chao $\mathrm{N}$ et al. Radiation injury after a nuclear detonation:

medical consequences and the need for scarce resources

allocation. Disaster Med Public Health Prep. 2011

Mar;5(S1 Suppl 1):S32-44. https://doi.org/10.1001/dmp.2011.17

3. Fukumoto R, Cary LH, Gorbunov NV, Lombardini

ED, Elliott TB, Kiang JG. Ciprofloxacin modulates

cytokine/chemokine profile in serum, improves bone

marrow repopulation, and limits apoptosis and autophagy

in ileum after whole body ionizing irradiation combined

with skin-wound trauma. PLoS One. 2013;8(3):e58389.

https://doi.org/10.1371/journal.pone.0058389

4. Dörr W, Emmendörfer H, Weber-Frisch M. Tissue kinetics

in mouse tongue mucosa during daily fractionated

radiotherapy. Cell Prolif. 1996 Sep;29(9):495-504.

https://doi.org/10.1111/j.1365-2184.1996.tb00992.x

5. Bralic M, Muhvic-Urek M, Stemberga V, Golemac M, Jurkovic S, Borcic J et al. Cell death and cell proliferation in mouse submandibular gland during early post-irradiation phase. Acta Med Okayama. 2005 Aug;59(4):153-9. https://doi.org/10.18926/AMO/31948

6. Dörr W, Hendry JH. Consequential late effects in normal tissues. Radiother Oncol. 2001 Dec;61(3):223-31. https://doi.org/10.1016/S0167-8140(01)00429-7

7. Samet N, Laurent C, Susarla SM, Samet-Rubinsteen N. The effect of bee propolis on recurrent aphthous stomatitis: a pilot study. Clin Oral Investig. 2007 Jun;11(2):143-7. https://doi.org/10.1007/s00784-006-0090-z

8. Rodríguez Rodríguez E, Darias Martín J, Díaz Romero

C. Aloe vera as a functional ingredient in foods. Crit Rev Food Sci Nutr. 2010 Apr;50(4):305-26. https://doi.org/10.1080/10408390802544454

9. Eamlamnam K, Patumraj S, Visedopas N, Thong-Ngam D. Effects of Aloe vera and sucralfate on gastric microcirculatory changes, cytokine levels and gastric ulcer healing in rats. World J Gastroenterol. 2006 Apr;12(13):2034-9. https://doi.org/10.3748/wig.v12.i13.2034

10. Banu A, Sathyanarayana B, Chattannavar G. Efficacy of fresh Aloe vera gel against multi-drug resistant bacteria in infected leg ulcers. Australas Med J. 2012;5(6):305-9. https://doi.org/10.4066/AMJ.2012.1301

11. Babaee N, Zabihi E, Mohseni S, Moghadamnia AA. Evaluation of the therapeutic effects of Aloe vera gel on minor recurrent aphthous stomatitis. Dent Res J (Isfahan). 2012 Jul;9(4):381-5.
12. Tan ML, Choong PF, Dass CR. Recent developments in liposomes, microparticles and nanoparticles for protein and peptide drug delivery. Peptides. 2010;3z:184 193. https://doi.org/10.1016/i.peptides.2009.10.002.

13. Wilkinson LJ, White RJ, Chipman JK. Silver and nanoparticles of silver in wound dressings: a review of efficacy and safety. J Wound Care. 2011 Nov;20(11):543-9. https://doi.org/10.12968/jowc.2011.20.11.543

14. Nasrollahi A, Pourshamsian K, Mansourkiaee P. Antifungal activity of silver nanoparticles on some of fungi. Int J Nanodimens. 2011;1(3):233-9. https://doi.org/10.7508/IJND.2010.03.007

15. Lara HH, Ayala-Nuñez NV, Ixtepan-Turrent L, RodriguezPadilla C. Mode of antiviral action of silver nanoparticles against HIV-1. J Nanobiotechnology. 2010 Jan;8(1):1. https://doi.org/10.1186/1477-3155-8-1

16. Chaloupka K, Malam Y, Seifalian AM. Nanosilver as a new generation of nanoproduct in biomedical applications. Trends Biotechnol. 2010 Nov;28(11):580-8. https://doi.org/10.1016/j.tibtech.2010.07.006

17. Kim KJ, Sung WS, Moon SK, Choi JS, Kim JG, Lee DG. Antifungal effect of silver nanoparticles on dermatophytes. J Microbiol Biotechnol. 2008 Aug;18(8):1482-4.

18. El-Batal Al, El-Baz AF, Abo Mosalam FM, Tayel AA. Gamma irradiation induced silver nanoparticles synthesis by Monascus Purpureus. J Chem Pharm Res. 2013;5(8):1-15.

19. Williams JP, Brown SL, Georges GE, Haver-Jensen M, Hill RP, Huser AK et al. Animal models for medical countermeasures to radiation exposure. Radiat Res. 2010 Apr;173(4):557-78. https://doi.org/10.1667/RR1880.1

20. Sullivan TP, Eaglstein WH, Davis SC, Mertz P. The pig as a model for human wound healing. Wound Repair Regen. 2001 Mar-Apr;9(2):66-76. https://doi.org/10.1046/j.1524-475x.2001.00066.x

21. Wang J, Boerma M, Fu Q, Haver-Jensen M. Radiation responses in skin and connective tissues: effect on wound healing and surgical outcome. Hernia. 2006 Dec;10(6):502-6. https://doi.org/10.1007/s10029-006-0150-y

22. Tomasek JJ, Gabbiani G, Hinz B, Chaponnier C, Brown RA. Myofibroblasts and mechano-regulation of connective tissue remodelling. Nat Rev Mol Cell Biol. 2002 May;3(5):349-63. https://doi.org/10.1038/nrm809

23. Hinz B, Celetta G, Tomasek JJ, Gabbiani G, Chaponnier C. Alpha-smooth muscle actin expression upregulates fibroblast contractile activity. Mol Biol Cell. 2001 Sep;12(9):2730-41. https://doi.org/10.1091/mbc.12.9.2730

24. Dormand EL, Banwell PE, Goodacre TE. Radiotherapy and wound healing. Int Wound J. 2005 Jun;2(2):112-27. https://doi.org/10.1111/j.1742-4801.2005.00079.x 
25. Li CJ, Wang SZ, Wang SY, Zhang YP. Assessment of the effect of local application of amifostine on acute radiation-induced oral mucositis in guinea pigs. J Radiat Res (Tokyo). 2014 Sep;55(5):847-54. https://doi.org/10.1093/irr/rru024 PMID:24706999

26. Kiang JG, Garrison BR, Gorbunov NV. Radiation combined injury: DNA damage, apoptosis, and autophagy. Adapt Med. 2010;2:1-10.

27. Somboonwong J, Thanamittramanee S, Jariyapongskul A, Patumrai S. Therapeutic effects of Aloe vera on cutaneous microcirculation and wound healing in second degree burn model in rats. J Med Assoc Thai. 2000 Apr;83(4):417-25.

28. Miller MB, Koltai PJ. Treatment of experimental frostbite with pentoxifylline and aloe vera cream. Arch Otolaryngol Head Neck Surg. 1995 Jun;121(6):678-80. https://doi.org/10.1001/archotol.1995.01890060076015

29. Chen J, Han CM, Lin XW, Tang ZJ, Su SJ. [Effect of silver nanoparticle dressing on second degree burn wound]. Zhonghua Wai Ke Za Zhi. 2006 Jan;44(1):50-2. Chinese.

30. Lu S, Gao W, Gu HY. Construction, application and biosafety of silver nanocrystalline chitosan wound dressing. Burns. 2008 Aug;34(5):623-8. https://doi.org/10.1016/i.burns.2007.08.020

31. Atiba A, Nishimura M, Kakinuma S, Hiraoka T, Goryo M, Shimada $Y$ et al. Aloe vera oral administration accelerates acute radiation-delayed wound healing by stimulating transforming growth factor- $\beta$ and fibroblast growth factor production. Am J Surg. 2011 Jun;201(6):809-18. https://doi.org/10.1016/j.amjsurg.2010.06.017

32. Jettanacheawchankit $S$, Sasithanasate $S$, Sangvanich $P$, Banlunara W, Thunyakitpisal P. Acemannan stimulates gingival fibroblast proliferation; expressions of keratinocyte growth factor-1, vascular endothelial growth factor, and type I collagen; and wound healing. J Pharmacol Sci. 2009 Apr;109(4):525-31. https://doi.org/10.1254/iphs.08204FP

33. Reynolds T, Dweck AC. Aloe vera leaf gel: a review update. J Ethnopharmacol. 1999 Dec;68(1-3):3-37. https://doi.org/10.1016/S0378-8741(99)00085-9

34. Melaiye A, Youngs JW. Silver and its application on antimicrobial agents. Expert. Opin. Ther. Pat. 2005;15:125-130 https://doi.org/10.1517/13543776.15.2.125

35. Sibbald RG, Contreras-Ruiz J, Coutts P, Fierheller M, Rothman A, Woo K. Bacteriology, inflammation, and healing: a study of nanocrystalline silver dressings in chronic venous leg ulcers. Adv Skin Wound Care. 2007 Oct;20(10):549-58. https://doi. org/10.1097/01.ASW.0000294757.05049.85

36. Liu X, Lee PY, Ho CM, Lui VC, Chen Y, Che CM et al. Silver nanoparticles mediate differential responses in keratinocytes and fibroblasts during skin wound healing. ChemMedChem. 2010 Mar;5(3):468-75. https://doi.org/10.1002/cmdc.200900502

37. Liu $L Y, C$ hen $X D, W u B Y$, Jiang $Q$. [Influence of Aloe polysaccharide on proliferation and hyaluronic acid and hydroxyproline secretion of human fibroblasts in vitro]. Zhong Xi Yi Jie He Xue Bao. 2010 Mar;8(3):256-62. Chinese https://doi.org/10.3736/jcim20100310

38. Davis RH, Donato JJ, Hartman GM, Haas RC. Anti-inflammatory and wound healing activity of a growth substance in Aloe vera. J Am Podiatr Med Assoc. 1994 Feb;84(2):77-81. https://doi.org/10.7547/87507315-84-2-77

39. Chithrani BD, Ghazani AA, Chan WC. Determining the size and shape dependence of gold nanoparticle uptake into mammalian cells. Nano Lett. 2006 Apr;6(4):662-8. https://doi.org/10.1021/nl052396o 